\title{
Volga Yılmaz-Gümüş*
}

\section{Solidity and Professionalization of Translation: Turkey as a Case in Point}

\begin{abstract}
This study sets out to describe the state of the translation (not interpreting) profession in Turkey, approached by means of indicators based on professionalization (university-based translator training, legal instruments introduced to regulate the market, and professional associations) and solidity of the profession (proportion of men vs. women, translation graduates working as translators, freelance vs. in-house translators, and commitment to the profession). The indicators are investigated by analyzing documents (such as Regulation on the Public Notary, the National Occupational Standards for translators and interpreters, and the Prime Ministry's report on the translation profession in Turkey), as well as survey and interview data gathered from the graduates of university translation programs, representing freelancers, in-house translators, and language teachers. The increasing number of university-based translation programs, legal instruments and translator associations suggests that continuous attempts have been made to enhance the degree of professionalization in translation. On the other hand, quantitative analyses of a survey administered to translation graduates indicate that the proportion of female translators is overwhelmingly high, that graduates tend to work as freelance translators, but freelancing is mostly not their main role, and that the graduates mostly have a positive perception of training, but do not feel prepared to enter the market after graduation. The findings of document and empirical analyses show that all traits of an established profession are still not present in translation while significant steps have been taken on the way to solidity and professionalization.
\end{abstract}

\section{Keywords}

Translation profession; translators; professionalization; solidity; translation market; translator training; translation associations

\section{Introduction}

Translation as a profession has been drawing academic interest in recent years, probably as a result of the increasing interest in the profession with the growing need for translation - the market factor - on the one hand, and the influence of sociological approaches in Translation Studies that focus on the human agents' roles in the act of translation - the research factor - on the other hand. We can now find a plethora of empirical studies and theoretical discussions on, for example, professionalization in translation (Sela-Sheffy 2006; Dam/Zethsen 2010), status of professional translators (Choi/Lim 2002; Dam/Zethsen 2008, 2009, 2011, 2016; Katan 2009a, 2009b, 2010; Ruokonen 2013, 2016), status/state of the translation profession (Pym et al. 2012; Kafi et al. 2017), the changing nature of the translation profession (Séguinot 2007), and non-professional translation (Pérez-González/Susam-Saraeva 2012; Olohan 2012, 2014; Sela-Sheffy 2016). These studies highlight, among other things, middling status as perceived by various populations including translation professionals (Dam/Zethsen 2009, 2011), professionals, teachers and students (Katan 2009b), and translation students (Ruokonen 2016), discussions on the role of certification and academic qualification (Chan 2013), shortcomings of professional codes of ethics (McDonough Dolmaya 2011; Kafi et al. 2017), lack of public recognition (Dam/Zethsen 2010; Choi/ Lim 2002), lack of regulation in entry to the profession (Pym et al. 2012; Kafi et al. 2017), and

\footnotetext{
* Department of Translation and Interpreting

Anadolu University

26470 Eskişehir, Turkey

vygumus@anadolu.edu.tr
} 
translation as a predominantly freelance occupation (Pym et al. 2012: 89). The results obtained in these studies indicate that translation is apparently a semi-profession, or an emerging profession in the sense that not all traits of a profession are fully developed in translation. With regard to the nature of the translation profession, "there is evidence to indicate that translation is mainly a part-time, freelance and transitory occupation, i.e. that the profession is porous and lacks a solid core" (Dam/Zethsen 2016: 175). Taking such discourse as a point of reference, this study seeks evidence for the (lack of) solidity of the translation profession in Turkey. Interpreting is not included, and the scope of this study is limited to translation.

The existing literature reveals only a few studies related to the state of the translation profession and the status of translators in Turkey (some examples are Kobya/Karabacak 2015, Uysal et al. 2015, Ersoy/Odacioğlu 2014, The Proceedings of the Ministry for EU Affairs Translation Platform 2012). These are mostly non-empirical studies focusing on historical professionalization developments, working conditions and specific problems of translators on the market, cooperation between stakeholders, standards and ethics, and what awaits translators on the way to accession to the EU. The literature provides only limited empirical data with regard to the state of the profession, and the profile of translators on the market.

The present study intends to contribute to accumulated knowledge regarding the translation profession by analyzing documentary and empirical data to describe the state of the translation profession in Turkey, and to seek evidence concerning its degree of professionalization and solidity. The first part of the analysis describes and summarizes various documents concerning translator training, translator associations, and legal instruments that have been introduced to regulate the profession in recent years. The second part of the analysis focuses on empirical data collected from the graduates of university-based translator-training programs by means of a survey $(n=125)$ and interviews $(\mathrm{n}=12)$.

This article first provides an overview of previous research on translation as a profession and the solidity of the translation profession (Section 2), followed by an overview of the methods used to analyze two themes of the study (Section 3). Section 4 investigates the degree of professionalization of translation in Turkey, drawing on the analysis of relevant documents. The results of the survey, and interviews with graduates are presented in Section 5. Finally, Section 6 discusses the results of the document analyses and data analyses of surveys and interviews, linking them to previous research (on the translation profession). The results of this study may be used for the purposes of comparison with related results from other countries to define the effects of cultural context on the profession, and as a benchmark of the present status of the profession, allowing for historical comparison to define any future changes in the state of the profession in Turkey.

\section{Previous research}

The present study focuses on two main themes to define the state of the translation profession in Turkey: the degree of professionalization and the solidity of the translation profession. The two sections below describe the indicators for professionalization and solidity, drawn from previous theories and research.

\subsection{The degree of professionalization in translation}

The questions of distinguishing professions from occupations and defining typical features of a profession are often central to studies on professionalization of a wide range of occupations, including for example translation (Katan 2009b), social work (Weiss-Gal/Welbourne 2008), nursing (Keogh 1997), journalism (Drechsel 2000) or public relations (Fitch 2016), in contrast to established professions such as law and medicine. These studies rely on typical traits that may be used to define the degree of professionalization. While there is currently no definite consensus on these traits, the lists used by various researchers include, more or less, the following traits listed by Millerson (1964 cited in Abercrombie/Hill/Turner 2006: 309): 
(1) the use of skills based on theoretical knowledge; (2) education and training in these skills; (3) the competence of professionals measured by examinations; (4) a code of conduct to ensure professional integrity; (5) performance of a service that is for the public good; (6) a professional association that organizes members.

In Translation Studies literature as well, there is a growing body of research that refers to these traits to describe the state or status of the translation profession in various cultural contexts. The first trait acknowledged in previous research is "specialized skills" based on theoretical/advanced knowledge. It is generally linked to "education or training" required to exercise a profession. Dam/Zethsen $(2008,2009,2010,2011,2016)$ used four parameters to determine and compare the status of Danish translators in a series of studies where status refers to perceptions of prestige and value. One of the four parameters is education/expertise (the others being salary/income, visibility, and power/influence). Jobs that require a high level of education and high degree of expertise and specialized knowledge are at the top of the prestige scale (Dam/Zethsen 2011: 986). Academic qualifications and professional qualifications are also included in Pym et al.'s (2016: 33) signals of status where the signals "indicate the relative trustworthiness of a translator". Similarly, in Katan's study based on the analysis of data from an online survey filled out by around 1,000 professional translators and interpreters, translation and interpreting lecturers, and translation and interpreting students worldwide, an overwhelming majority of the respondents described translating and interpreting as a profession, particularly mentioning skills/competences/expertise, knowledge and education (Katan 2009a: 123; Katan 2009b: 192). However, the importance/role of training on the translation market is unclear. OPTIMALE's survey of employers (Toudic 2012: 6) shows that professional experience is considered slightly more important than an academic degree $(88 \%$ of the employers see experience as important or essential while $78 \%$ of them believe that academic degree in translation is essential or very important).

The second trait that distinguishes an occupation from a profession is "the competence of professionals measured by examinations", which may be linked to any legal procedures that regulate entry to the profession, legal instruments related to translation and translator certification, and extended to cover a code of conduct to ensure professional integrity. Weiss-Gal/Welbourne (2008: 283) defined "the existence of laws and licensing procedures" as an indicator of public recognition of a profession. Katan's (2009a: 113) contention is that the translation profession is "almost totally unregulated" due to lack of regulations concerning entry to the profession, professional conduct and quality control. In Katan (2009b: 193), the respondents that did not define translating as a profession mentioned mainly the lack of certification and the lack of public recognition. Nevertheless, various kinds of certifications for translators do exist, in the sense of "a voluntary process by which an organization grants recognition to an individual who has met certain predetermined qualification standards" (Stejskal 2004: 6). The organization can be a professional association, a government or an academic institution (Stejskal 2004). However, such certification may be limited in scope (see Section 4.2. for details about sworn translators in Turkey) or not sufficiently recognized or valued on the market. For example, Chan (2009: 169), in his research mainly with translator recruiters, concluded that the recruiters were inclined to value education more than certification.

The third major trait of professionalization is the existence of "a professional organization that organizes members". Translators associations are reported to play an essential role in improving the state of the profession (Pym et al. 2012: 33; Uysal et al. 2015: 260; Ruokonen 2016: 204). As emphasized in Pym et al. (2012: 33), membership of a professional association is a clear indicator of professional status, and a professional association's authority derives from collective factors rather than individual members' expertise. The key factors they consider in the evaluation of associations are "admission criteria, longevity, size (number of members), inclusion in wider or parent associations, specialisation, and in some cases the number and quality of services to members and public interventions" (Pym et al. 2012: 33). 
Relying on previous research and data available in the Turkish context, the present study refers to these three aspects, i.e. education, regulations and professional organizations, to define the degree of professionalization of translation in Turkey. Item 5 in Millerson (1964), i.e. "performance of a service that is for the public good", goes beyond the scope of this study, requiring further and specific data collection.

\subsection{The solidity of the translation profession}

The present section of the study seeks to identify indicators of the solidity of the translation profession based on the methodology and results of previous studies. There is no consensus on what makes a profession solid, but the indicators used in the literature may play a guiding role. Dam/ Koskinen (2016: 3) link the solidity of the profession to the profile of translators and how the profession develops, i.e. translation as a "female, part-time, freelance and transitory occupation" as opposed to translation as a "more gender-balanced, full-time, salaried (in-house), life-long occupation". They also mention the relationship between untrained and trained professionals (2016: 4). Similarly, Dam/Zethsen (2016: 175) refer to part-time, freelance and transitory nature of the translation profession as signs of a profession that "is porous and lacks a solid core".

With regard to the gender aspect, Pym et al.'s (2012: 85) survey of previous studies suggests that the translation market is globally characterized by the predominance of women. An explanation for this is that the profession allows part-time and freelance work (Pym et al. 2012: 86).

Freelancing, as opposed to being an in-house employee, is a common mode of work in the translation profession. Olohan (2007), drawing upon a meta-analysis of data collected from Canada, the United Kingdom, and Germany, reports that after graduation, translators mostly have to work freelance. Olohan (2007: 55-56) further asserts that training programs are required to prepare students for freelancing, and even at the beginning of their training, make students aware that they may be employed as freelancers in the sector, and that freelancing is "a mode of working" with certain advantages rather than "a last resort". Fraser/Gold (2001), having surveyed freelance translators in the United Kingdom, found that the respondents chose freelancing for various reasons, including a change of circumstances $(23 \%)$, aspiration to be a freelancer $(22 \%)$, and need for a change from a non-translation job (17\%) (Fraser/Gold 2001: 685). Seventy percent of the respondents who said "no in-house jobs were available" were aged between 25 and 34, which may mean that freelancing is a way of entering the market for new graduates (Fraser/Gold 2001: 686). Fraser/Gold's (2001: 687) survey further reveals that freelancing, at least at the time of the survey, was a preferred option rather than a compulsory choice for most translators in the United Kingdom. A study by Byrne (2003) corroborates Fraser/Gold's results on the scarcity of in-house positions, reporting that only eight of 37 graduates in 1999 and six of 38 graduates in 2000 from a BA program in Ireland found employment as a translator. As a result, there is a "need for a separate module to be included on [sic] training programmes which will arm students with the specialised knowledge they need in order to become professional, freelance translators and to run a successful and efficient business" (Byrne 2003). In Lagoudaki's global survey (2006: 8) of 874 translation professionals, $48 \%$ of the respondents mentioned that they were freelancers "working independently without an agency". In Setton/Guo Liangliang's (2009: 221) survey with 62 translators and interpreters in Shanghai and Taipei, nearly half of the respondents were freelancers. Going through these and other studies, Pym et al. (2012: 89) calculate that the general proportion of freelancers is around 78.4 percent or more fairly ranges "from 50 to 89 percent, depending on the country and the sector".

With regard to the proportion of untrained versus trained professionals, previous research presents limited data on the proportion of translators holding a university degree in translation. In Katan's (2009b: 201) global survey only slightly over half (55\%) of the respondents had university training in either translation and interpreting or language studies. 
Another indicator that Dam/Koskinen (2016) consider to define the solidity of this profession is whether practitioners see translating as a transitory or life-long occupation. This can be investigated by surveying translators' views on changing professions and their job satisfaction. Setton/Guo Liangliang (2009: 222) report that half of their respondents were satisfied or very satisfied with their job, and over half of them had no plans to change their job. Similarly, in Katan's (2009a: 148) survey, the majority of respondents were pretty satisfied (50\%) or extremely satisfied (21\%) with the profession. The data Dam/Zethsen (2016: 179-182) collected from fifteen agency translators suggest that the respondents find translation "exciting and satisfying", "varied, stimulating and never boring", "an intellectual and creative challenge", and "important and therefore meaningful". Thus, despite indications of the low and middling status of the profession, the majority of translators have no intention to change their job.

Dam/Zethsen (2010: 196-197) define translation in Denmark as a semi-profession or an emerging profession, "aspiring to become a full profession". Studies in other contexts indicate that this description has broader validity. Translation as an occupation has gained a certain degree of professionalization and solidity, but does not possess all traits of a profession. The aim of the present study is to investigate translation in the Turkish context with regard to professionalization and solidity. Acknowledging that translation has not developed into a full profession yet, this study labels it as the translation profession, echoing the aspiration and tendency in Translation Studies literature.

\section{Methods and data}

Qualitative and quantitative methods were combined to approach the two main themes dealt with in this study, i.e. the degree of professionalization and the solidity of the translation profession. Table 1 provides an overview of the methods and data used to describe each aspect. 


\begin{tabular}{|c|c|c|}
\hline Aspect & Source of data & $\begin{array}{l}\text { Method and specific } \\
\text { research question }\end{array}$ \\
\hline \multicolumn{3}{|l|}{ 1) Professionalization } \\
\hline \multirow[t]{4}{*}{ Education/expertise/training } & $\begin{array}{l}\text { Information collected } \\
\text { from websites of } \\
\text { university-based training } \\
\text { programs }\end{array}$ & $\begin{array}{l}\text { Qualitative: Comparing and } \\
\text { summarizing the data from } \\
\text { websites of university-based } \\
\text { training programs to establish } \\
\text { an overview of translator } \\
\text { training }\end{array}$ \\
\hline & $\begin{array}{l}\text { Survey of translation } \\
\text { graduates }\end{array}$ & Quantitative: \\
\hline & & $\begin{array}{l}\text { - How do graduates see the } \\
\text { role of education? }\end{array}$ \\
\hline & & $\begin{array}{l}\text { - How did the training prepare } \\
\text { them for work? }\end{array}$ \\
\hline $\begin{array}{l}\text { Legal } \\
\text { instruments/certification/standards }\end{array}$ & $\begin{array}{l}\text { Information collected } \\
\text { from regulations, } \\
\text { standards and reports } \\
\text { related to profession }\end{array}$ & $\begin{array}{l}\text { Qualitative: Summarizing the } \\
\text { data from the relevant sources } \\
\text { to provide an overview of } \\
\text { legal instruments and } \\
\text { standards that indicate } \\
\text { professionalization }\end{array}$ \\
\hline Professional associations & $\begin{array}{l}\text { Information collected } \\
\text { from websites of } \\
\text { associations, and } \\
\text { Translation Platform } \\
\text { proceedings }\end{array}$ & $\begin{array}{l}\text { Qualitative: Comparing and } \\
\text { summarizing the data from } \\
\text { websites of associations to } \\
\text { provide an overview of } \\
\text { translators' associations } \\
\text { especially with regard to } \\
\text { longevity, number of } \\
\text { members, and admission } \\
\text { criteria }\end{array}$ \\
\hline \multicolumn{3}{|l|}{ 2) Solidity } \\
\hline Men vs. women & Survey & $\begin{array}{l}\text { Quantitative: What is the } \\
\text { proportion of men and women } \\
\text { among graduates? }\end{array}$ \\
\hline \multirow[t]{3}{*}{ Graduates working as translators } & Survey & Quantitative: \\
\hline & & $\begin{array}{l}\text { - How many graduates work } \\
\text { as translators? }\end{array}$ \\
\hline & & $\begin{array}{l}\text { - How many graduates } \\
\text { indicate translation as their } \\
\text { first role? }\end{array}$ \\
\hline Freelance vs. in-house & Survey, interviews & $\begin{array}{l}\text { Quantitative: How many } \\
\text { graduates work as freelancers? }\end{array}$ \\
\hline
\end{tabular}

Table 1. Methods and data used to describe the degree of professionalization and the solidity of the profession

The aspects of professionalization mainly rely on the analysis of documents, including websites of university-based translator-training programs and professional associations, the Regulation on the Public Notary, the National Occupational Standards ${ }^{1}$ for translators and interpreters introdu-

1 The Law no. 5544 on the Vocational Qualifications Authority defines National Occupational Standard as "[minimum norms adopted by the Authority, which prescribe the possession of necessary knowledge, skills, attitudes and 
ced by the Vocational Qualifications Authority of Turkey, and the Prime Ministry's report on the translation profession in Turkey.

The aspects of solidity of the profession mainly draw on the results of a survey of translation program graduates and further interviews with graduates. The data were collected between 2010 and 2012 as part of a larger project that explores whether translator training in Turkey responds to the expectations of the translation market. This paper analyzes data on the profile of translators, allowing me to come to conclusions regarding the solidity of the translation profession in Turkey.

The survey data were collected from the graduates of two undergraduate translator-training programs in Turkey. Given that the number of translator-training programs has been increasing, there is a large population of translation graduates. I restricted the study to the graduates of two translator-training programs in Ankara: Hacettepe University and Bilkent University. These cases represent the two types of universities in Turkey, i.e. state and foundation-funded universities. Hacettepe University, which has been training translators since 1982, was the first state university to establish a department of translation and interpreting, and Bilkent was the first foundation-funded university to establish a department of translation and interpreting, in 1993. The year of graduation was not taken into consideration when distributing the survey link.

The data-collecting instrument was an online questionnaire consisting of 21 questions. ${ }^{2}$ Survey Monkey, which provides the opportunity to create a questionnaire based on a default template, was used. The language of the survey was English. The survey form first asks for demographic data, including sex, age, and educational background. The subsequent questions seek to find out 1) the main roles of graduates (e.g. translator, interpreter, trainer, researcher, etc.) and if they do not work in the translation, interpreting and localization sectors, the reasons for this, 2) professional data, including years of experience in translation, interpreting or localization, specialization areas in translation, and any activities carried out to improve translation skills, 3) whether graduates believe that all professional translators should have a degree in translation or if translation is best learned on the job, 4) how frequently particular course components, such as communication skills in A and B languages, translation practice, translation theory, translation criticism and translation technology, were dealt with in their training program, 5) how graduates rate the importance of course components with regard to their professional work, 6) their perceptions of how well their academic training prepared them for professional work, and 7) their perceptions of the frquency and forms of interaction between academic training and the translation market. This study reports on the results of points 1,3 and 6 , which are directly related to the aim of this study.

Following completion of the survey, interviews were conducted with twelve graduates, representing in-house translators, freelancers and language teachers. In the survey forms, 60 of the 125 respondents agreed to be interviewed and provided their contact information. These respondents were categorized into three according to their main role: in-house translators (those working as a translator in an institution or a translation company), freelance translators, and language teachers. I left out those whose main role is another profession since the focus of the study is on translator training and the translation market. Language teachers were also interviewed, as they constitute about $25 \%$ of the respondents, which is a figure worthy of note, given that students were originally trained as translators and interpreters in the university-based programs included in this study. I further categorized the respondents according to the university they graduated from. Maximum variation sampling, which is a type of purposive sampling, was used to ensure that each profession (main activity) and university was represented in interviews.

The present study reports on the particular survey results related to the professional profile of translation graduates, and adds data from interviews, when required. Other results of the study fall beyond the scope of this paper, and are presented elsewhere (Yilmaz Gümüş 2014, YılmazGümüş 2017).

behaviors required for the successful performance of a profession."

2 The questionnaire was posted at http://www.surveymonkey.com/s/YHWKQ2H. 


\section{On the degree of professionalization in translation in Turkey: education, legal instruments, and professional associations}

Drawing upon the discussions in previous research and analysis of relevant documents, this section of the study describes education, legal instruments and standards, and translator associations, which suggest that continuous attempts have been made to enhance the degree of professionalization in translation in Turkey.

\subsection{Education}

As summarized in Section 2.1., specialized skills and expertise based on education constitute one of the typical and traditional traits of a profession. University-based translator training started in Turkey in the first half of the 1980s with the launch of four-year undergraduate programs. The 2016 Guide of the Evaluation, Selection and Placement Center (ÖSYM) for higher-education institutions in Turkey lists 32 universities that offer translator and interpreter training for a four-year undergraduate degree. In the last decade, particularly with the establishment of numerous foundation-funded universities ${ }^{3}$, the number of translation and interpreting programs has grown rapidly. Undergraduate programs are considered the main workforce provider to the market. However, the forms of translator training in universities have been diversifying, and some universities offer associate-degree ${ }^{4}$, master' ${ }^{5}$ and doctorate programs as well. Being established after 2012, associate-degree programs in translation have a shorter history in the Turkish higher education system.

When students enter an undergraduate translation and interpreting program, they graduate as a translator and an interpreter. Although some universities offer a specialized interpreting program in the final year to students that fulfill certain criteria, they give the diploma of Translator and Interpreter to all their graduates, regardless of whether the student has specialized in interpreting. In most of these universities, the program is named Translation and Interpretation/Interpreting (referred to in Turkish with the words of Arabic origin, Mütercim Tercümanllk). There are also universities that prefer Translation (and Interpreting) Studies (Çeviribilim i.e. Science of Translation). ${ }^{6}$

University-based programs not only train professionals for the market but also contribute to the creation of a knowledge base related to translation (studies). There is now a broad array of specialized channels in Turkey used to disseminate and exchange knowledge of translation at the national and international level, including academic journals, textbooks, conferences, and meetings and online discussion groups that bring together academics and professionals.

3 Foundation-funded universities, whose establishment was first permitted in the 1982 Constitution of Turkey, are subject to the constitutional provisions for higher education institutions founded by the state with regard to academic work, recruitment of academic members and security, excluding financial and administrative issues (Article 130). Established by foundations and not by the state, these higher education institutions must function without the purpose of gaining income, profit and rights (Article 27 of the Regulation on Foundation-Funded Higher Education Institutions). Thus, although they receive tuition fees from students, these institutions do not have the status of private universities. The number of these universities has reached about 75 by 2017.

4 In the Turkish higher education system, an associate degree corresponds to level 5 of the EQF of 2008 and to the short cycle higher education according to the Dublin descriptors of 2004. The Higher Education Council of Turkey (2007: 29) states that the purpose of the associate degree is to enable students to acquire an occupation in a short period of time after vocational or non-vocational secondary education, and to augment diversity in human resources. The normal period of study required to obtain an associate's degree is four semesters.

5 In the Turkish higher education system, the period of a master's study is four semesters (two years) and may be extended to maximum three years.

6 "Translation and Interpreting Studies" or "Translation Studies" corresponds to Çeviribilim in Turkish. Çeviribilim is a term that literally means "science of translation" and is used in a way to encompass both Translation Studies and Interpreting Studies. 


\title{
4.2. Legal instruments and standards
}

Any regulations regarding entry to the market, earning credibility on the market, and setting standards also have implications for the degree of professionalization. In Turkey, the translation market employs not only the graduates of translator-training programs, but is open to the graduates of foreign-language teaching, linguistics and foreign language and literature departments, or in some cases, anyone speaking a foreign language. The only certification system concerns sworn translators. Translators are required to apply to a public notary to become a sworn translator, and submit proof that they have proficiency in the language combination for which they apply. The related clause of the Regulation on the Public Notary reads as follows: "The public notary should ensure without any doubt that the translator knows said language or script accurately, seeing their diploma or other documents, or by other ways." ${ }^{\prime 7}$ Anyone who submits proof of language proficiency and takes an oath before a public notary can become a sworn translator.

There have been some efforts to regulate entry to the market and improve quality on the market. The translation into Turkish and adoption by the Turkish Standards Institution of EN 15038:2006, European Quality Standard for Translation Service Providers, is one of these efforts. This quality standard, developed by the European Committee for Standards (CEN), includes "general rules for management, physical structure and personnel characteristics of work places giving translation services". In 2015, the Turkish Standards Institution adopted TS EN ISO 17100, which is based on EN ISO 17100:2015 Translation services - Requirements for translation services, to replace TS EN 15038. All translation service providers can seek certification. Translation service providers do not have to comply with these standards. However, clients are more likely to expect compliance as evidence for quality, as they now develop greater awareness about translation quality.

A relatively recent development related to the translation industry is the National Occupational Standards ${ }^{8}$ for translators and interpreters introduced by the Vocational Qualifications Authority of Turkey in 2013. The standards place the translation profession at level 6 according to the European Qualifications Framework (EQF), which requires

\begin{abstract}
advanced knowledge of a field of work or study, involving a critical understanding of theories and principles; advanced skills, demonstrating mastery and innovation, required to solve complex and unpredictable problems in a specialized field of work or study; competence to manage complex technical or professional activities or projects, taking responsibility for decision-making in unpredictable work or study contexts and to take responsibility for managing professional development of individuals and groups.
\end{abstract}

The standards, which will finally develop into national qualifications for translators, were drawn up with the cooperation of academics from university-based translation programs, professionals, and associations under the supervision of the Vocational Qualifications Authority. One of the shortcomings of the document is that the standards address translation and interpreting together, treating them as a single profession (Özkaya 2015: 64). The document of standards consists of four parts, i.e. introduction, description of the profession (definition of the profession, place of the profession in international classification systems, regulations related to health, security and environment, legislation related to the profession, working environment and conditions and other requirements related to the profession), profile of the profession (duties, procedures and performance criteria, tools, instruments and equipment used, knowledge and skills, attitudes and behaviors), and measurement, assessment and certification. The standards apply to the translation and interpreting professions together. However, qualifications are more specialized, being currently written for liaison interpreting, conference interpreting, community interpreting, specialized translation, and localization. The Coordination Group is working on qualifications, the draft of

7 The translation is my own.

8 The Law no. 5544 on the Vocational Qualifications Authority defines National Occupational Standards as "[m] inimum norms adopted by the Authority, which prescribe the possession of necessary knowledge, skills, attitudes and behaviors required for the successful performance of a profession." 
which will be shared soon with stakeholders. Then, a certification system will be developed based on qualifications.

A bill of law regarding the establishment of national and local chambers of translators was submitted to the Grand National Assembly of Turkey with a view to improving working conditions of translators, protecting their rights, supporting their work, raising awareness of the profession, promoting solidarity and taking measures to prevent unemployment. The bill proposes that a chamber is established in each province where there are at least 25 translators. A translator practicing the translation profession is required to apply for membership to the chamber in the said provincial area. This law has not been adopted yet. With regard to the establishment of chambers, the initial report of Prime Ministry Directorate for Administration Development (2011: 30) suggests that the lack of translators' chambers is one of the main problems of public sector translators. Affiliation with a chamber may eliminate the problems arising from the obligation for sworn translators to work affiliated with a public notary and remove the need for public notary endorsement for translations produced by sworn translators. However, a revised version of the report (2015: 51) suggests that coming together under the roof of a chamber particularly applies to tradespeople and is against the nature of the translation profession. Thus, organizations in the form of associations that gather under a federation respond more to needs of the translation profession.

\subsection{Professional associations}

Another element that is linked to the degree of professionalization is associations established to defend the rights of professionals. The relevant associations in Turkey are summarized in Table 2, paying particular attention to longevity, inclusion in wider associations and admission criteria (see Pym et al 2012 in Section 2.1. above).

\begin{tabular}{llll}
\hline Name & Established in & Member of & Membership criteria \\
\hline $\begin{array}{l}\text { Conference } \\
\text { Interpreters }\end{array}$ & 1969 & - & - References from at least three members \\
$\begin{array}{l}\text { Association of } \\
\text { Turkey (TKTD) }\end{array}$ & & & $\begin{array}{l}-150 \text { days of work as a conference } \\
\text { interpreter }\end{array}$ \\
& & & $\begin{array}{l}\text { - Pre-examination, and interview when } \\
\text { required }\end{array}$ \\
\hline $\begin{array}{l}\text { Translators' } \\
\text { Association of } \\
\text { Türkiye (TÜÇED) }\end{array}$ & 1992 & FIT & - Professional involvement in translation \\
& & & - Evidence of language proficiency \\
\hline $\begin{array}{l}\text { Translation and } \\
\text { Interpreting } \\
\text { Association of } \\
\text { Turkey }\end{array}$ & 1999 & FIT & - Tax registration certificate (from taxpayers) \\
\hline $\begin{array}{l}\text { Translators' } \\
\text { Association }\end{array}$ & 2006 & & - Professional involvement in translation \\
Turkey (ÇEVBİR) & & CEATL & $\begin{array}{l}\text { - Having translated a work that is covered by } \\
\text { the law on Intellectual Property Rights }\end{array}$ \\
\hline $\begin{array}{l}\text { Association of } \\
\text { Playwrights } \\
\text { and Translators } \\
\text { (OYÇED) }\end{array}$ & 2007 & & - Having written, adapted or translated at \\
\hline
\end{tabular}




\begin{tabular}{llll}
\hline $\begin{array}{l}\text { Association } \\
\text { of Translation }\end{array}$ & 2007 & EUATC & - Professional involvement in translation \\
Companies (Çİ) & & - References from at least two members \\
\hline
\end{tabular}

Table 2. Translator associations in Turkey

With regard to longevity, translator associations have a quite recent history in Turkey, excluding the Conference Interpreters Association of Turkey9 (Türkiye Konferans Tercümanları Derneği, TKTD) originally established as the Association of Conference Interpreters in 1969. The number has increased since the 1990s and the 2000s. Today, internet search results provide several associations of translation professionals:

The Translators' Association of Türkiye ${ }^{10}$ (Türkiye Çevirmenler Derneği, TÜÇED), a member of the International Federation of Translators (FIT), was established in 1992 to observe the rights and improve the status of translators. The association admits members under eight categories, including practicing translators (those who are individual taxpayers and employed in public or private organizations), translation company owners and language-related job holders in the tourism sector. The association gives, upon request, 'registration documents' to translation companies and to individual translators. While the latter are called 'translator's license' (which suggests a certification procedure), they are not based on an examination and assessment process. They are not recognized at the national level, either.

The Translation and Interpreting Association of Turkey ${ }^{11}$ (Çeviri Derneği), founded in 1999 and also a member of the FIT, represents the stakeholders of the translation and interpreting processes (i.e. translators, interpreters, proofreaders, translation companies, publishers and academics). The condition for full membership is professionalism based on qualified experience in translation.

The Translators' Association Turkey ${ }^{12}$ (Çevirmenler Meslek Birliği, ÇEVBİR), a member of the European Council of Literary Translators' Associations (CEATL), was established in 2006. The Association accepts the membership of translators who have translated a work that is covered by the Law on Intellectual Property Rights, e.g. a book or part(s) of a book, a movie, etc.

The Association of Translation Companies ${ }^{13}$ (Çeviri İşletmeleri Derneği, ÇID), a member of the European Union of Associations of Translation Companies (EUATC), was founded in 2007. It is an organization that aims to bring together translation companies under one roof.

Finally, two federations have been established recently to bring together local and national translator associations. These are the Federation of International Translators and Translation Agencies ${ }^{14}$ (Uluslararası Çevirmenler ve Çeviri Kuruluşları Federasyonu, TUÇEF) and the Certified Translation Federation ${ }^{15}$ (Yeminli Çevirmenlik Federasyonu, TURÇEF). The Turkish Union of Translation Students (Türkiye Çeviri Ögrencileri Birliği, TÜÇEB) was founded by students of translation and interpreting departments in 2010.

On the whole, the increasing number of university-based training programs, new initiatives (e.g. standards, bill of law) taken to regulate the market, and the establishment of several translators' associations are indicative of the progress that the occupation has made to develop into a

9 The English names of the associations are written out here as they appear either on official websites of respective associations or on related websites.

10 http://www.tuced.org.tr/. Accessed May 2017.

11 http://ceviridernegi.org/. Accessed May 2017.

12 http://cevbir.org.tr/. Accessed May 2017.

13 http://www.cid.org.tr/. Accessed May 2017.

14 http://www.tucef.org/. Accessed May 2017.

15 http://www.turcef.net/. Accessed May 2017. 
profession. The degree to which these efforts have contributed to professionalization is discussed and evaluated in Section 6.1. below.

\section{On the solidity of the translation profession: survey and interview results}

The survey conducted with 125 graduates of two university-based translator-training programs and further exchanges and interviews with graduates provide significant data with regard to the profile of translators in Turkey. The factors analyzed below, bearing on the solidity of the profession, include the proportion of men versus women, proportion of graduates working as translators, proportion of freelancers, graduates' commitment to the profession and views of their training.

\subsection{Female predominance in the translation profession}

Table 3 presents the distribution of respondents by sex:

\begin{tabular}{|l|l|l|}
\hline Sex & Number & Rate (\%) \\
\hline Women & 105 & 84.0 \\
\hline Men & 20 & 16.0 \\
\hline Total & 125 & 100 \\
\hline
\end{tabular}

Table 3. Distribution of the respondents by sex

A total of 125 respondents completed the survey. Table 1 shows that the number of female respondents ( 105 , corresponding to $84.0 \%$ of the total respondents) outweighed the number of male respondents $(20$, or $16.0 \%)$.

\subsection{Main roles of translation graduates}

The results related to main professional activities of translators are provided in Table 4:

\begin{tabular}{|l|l|l|l|l|}
\hline Professional activities & First & Second & Third & $\begin{array}{l}\text { Response } \\
\text { count }\end{array}$ \\
\hline Translator: & & & & \\
- In-house translator in an institution & $82.6 \%(38)$ & $15.2 \%(7)$ & $2.2 \%(1)$ & 46 \\
- Translator in a translation company & $61.5 \%(8)$ & $30.8 \%(4)$ & $7.7 \%(1)$ & 13 \\
- Freelancer & $38.6 \%(27)$ & $48.6 \%(34)$ & $12.9 \%(9)$ & 70 \\
\hline Interpreter & $61.2 \%(30)$ & $28.6 \%(14)$ & $10.2 \%(5)$ & 49 \\
\hline Language teacher & $85.3 \%(29)$ & $8.8 \%(3)$ & $5.9 \%(2)$ & 34 \\
\hline Editor & $26.7 \%(4)$ & $40.0 \%(6)$ & $33.3 \%(5)$ & 15 \\
\hline Translation and/or interpreting researcher & $72.7 \%(8)$ & $27.3 \%(3)$ & $0.0 \%(0)$ & 11 \\
\hline Translation project manager & $20.0 \%(2)$ & $40.0 \%(4)$ & $40.0 \%(4)$ & 10 \\
\hline Translator and/or interpreter trainer & $57.1 \%(4)$ & $14.3 \%(1)$ & $28.6 \%(2)$ & 7 \\
\hline Localization specialist & $33.3 \%(2)$ & $50.0 \%(3)$ & $16.7 \%(1)$ & 6 \\
\hline
\end{tabular}

Table 4. Main professional activities of the respondents as percentages of respondents in each activity

Out of 125 graduates, 89 individual respondents (71.2\% of all respondents) reported that they were working as translators. These 89 respondents had translation either as their first, second, or third role. The table looks different from the data reported below given that the respondents were 
allowed to select more than one option as their first, second or third role. For instance, respondents could mention both language teaching and freelancing as their first role, or both interpreting and editing as their second role. They were also allowed to choose, for example, translator in a translation company as their first role and freelancing as their second role.

Over half of the respondents defined their first role as translator (71 translators), i.e. in-house translator, translator in a translation company, or freelancer. Thirty-nine respondents $(31.2 \%)$ mentioned translation as their second or third role. Eight respondents $(6.4 \%)$ defined their first role only as interpreting, and 21 respondents $(16.8 \%)$ gave equal weight to translation and interpreting as the main role. Only nine translators $(7.2 \%)$ were employed in a translation company. Given the large number of translation companies in Turkey and the increasing need for professionals in these companies, it is remarkable that less than $10 \%$ of the graduates among the respondents were employed as full-time translators for a translation company.

In addition, 34 graduates in the respondent group were working as language teachers, which corresponds to $27.2 \%$ of the total graduates surveyed. Of the total respondents, 29 graduates $(23.2 \%)$ mentioned that language teaching was their first role. Seventeen respondents (13.6\%) defined some other profession than translator, interpreter or teacher as their main role, including editor, translator and interpreter trainer and researcher, marketing director or administrative assistant.

\subsection{Freelancing: a temporary or a permanent option?}

Table 4 above shows that about half the respondents defined freelance translation as their first or second role (48.8\%). Yet, it is notable that freelancing appears as a second role $(48.6 \%)$ rather than the first (38.6\%) among the respondents that chose freelancing as one of their roles. About $10 \%$ of the graduates mentioned freelancing as their main role together with another main role such as in-house translating, language teaching, interpreting and research, which means that they gave equal weight to freelancing and another role. The results indicate that although half the graduates were freelancing, they did not prefer it as their sole professional activity. Table 5 presents the breakdown of freelancers by graduation year.

\begin{tabular}{|l|l|l|l|}
\hline Freelancers graduated in & $\begin{array}{l}\text { Number } \\
\text { of freelancers }\end{array}$ & $\begin{array}{l}\text { Total number of } \\
\text { graduates }\end{array}$ & $\begin{array}{l}\text { Freelancer rate } \\
\mathbf{( \% )}\end{array}$ \\
\hline $1996-2000$ & 7 & 14 & 50.00 \\
\hline $2001-2005$ & 19 & 39 & 48.71 \\
\hline $2006-2010$ & 44 & 72 & 61.11 \\
\hline
\end{tabular}

Table 5. Distribution of freelancern by graduation year as percentage of the total number of respondents falling under the respective category of graduation year

With respect to graduation year, the rate of freelancers among the recent graduates $(61.11 \%)$ was higher compared to the graduates in the earliest group (50.00\%) and the mid-group (48.71\%). The younger the graduates were, the more they tended to freelance. This may indicate that freelancing is a way of entering the market. After the survey, I had interviews with three freelancers. One interviewee was freelancing because he was looking for a permanent job, and another had been freelancing but gave it up for a regular job and a salary as a language teacher. Only one graduate preferred freelancing, after working as a journalist and an in-house translator and project manager, and he has been satisfied with his work conditions and income.

\subsection{Commitment to the profession}

Commitment to the profession was not addressed directly in the survey and interviews. The data on the respondents' main roles reported in Section 5.2. show that, on the one hand, over $70 \%$ of 
the respondents worked as translators at least part of their time. On the other hand, about $23 \%$ of the respondents chose teaching and about $13 \%$ chose something other than translation, interpreting and teaching as their first role. The graduates' replies to why they do not prefer to work as a translator and why they prefer language teaching to translating throw further light on their commitment to the profession and intentions to change profession.

The graduates were asked to state their reasons if they did not work in the translation, interpreting and localization sectors. The responses of 43 participants to this open-ended question can be classified into the following five categories: ${ }^{16}$

1) working conditions (mainly financial dissatisfaction, i.e. the respondents believe that translators are underpaid given factors such as heavy workload, irregularity of working hours, high stress and little respect for the profession),

2) preference for another job because they enjoy it more,

3) lack of job opportunities (two mentioned that it was hard to work as a translator in smaller cities, and others said they could not find work as a translator or interpreter),

4) graduate studies (some respondents are doing an $\mathrm{MA}$ or a $\mathrm{PhD}$ and find translating and interpreting too demanding to be combined with graduate studies), and

5) other reasons (such as no room to advance in their career, translation is "boring", and the market is "challenging" because professionals without a translation degree are working for lower fees).

A significant finding of this survey is that language teaching is the strongest alternative to translating among the graduates of translation and interpreting programs. Out of 125 respondents, a large proportion defined language teaching as one of their roles (34 respondents; 27\%), with 29 respondents $(23 \%)$ defining language teaching as their first role. In order to discover why these students studied translation and interpreting if they were to be employed as language teachers after graduation, I had further exchanges with eight survey respondents currently working as language teachers, asking about their initial reasons for studying translation, and the factors that led them to work as language teachers after graduation. Their replies also provide insight into translation program graduates' commitment to the profession.

With respect to the reason for studying translation, three interviewees mentioned that they started studying translation with the intention of being a translator. The other five interviewees said that they made a choice according to the score they received in the university entrance examination. They were all planning a career related to foreign languages. After receiving relatively high scores on the exam, they chose translation and interpreting - the most popular language-related program when they took the university entrance examination.

Regarding the factors that led them to work as language teachers after graduation, eight translation graduates, now employed as teachers, had many reasons from financial status to private life for preferring teaching to translating. Only one respondent noted that she was seeing teaching as a temporary job and looking for a better job in translation. The others were inclined to continue in the teaching profession. The reasons that led translation graduates to choose teaching after graduation are mostly linked to disadvantages of the translation profession and partly similar to the open-ended responses reported above: imbalance between the effort and income in translation jobs, lack of standards related to the profession, stress factor in the job (it is difficult to have control over one's own work and workload when working as a translator), less interaction with other people (translation as a "desk job"), lack of job opportunities in smaller cities, and insufficiency of training programs in preparing trainees for the market. Advantages of the teaching profession also influenced their choice: more favorable working conditions especially in terms of working

16 Some respondents who were not mainly engaged in translation, but had translation as a second or third role also replied to this question. 
hours and holiday, job security (when employed in public schools and universities), greater interaction with people, and job satisfaction increased by receiving immediate feedback from learners.

\subsection{Graduates' perceptions of training}

Two further findings provide some insight into the solidity of the translation profession. First, the participants were asked to assess the role of a formal degree as opposed to on-the-job training:

\begin{tabular}{|l|l|l|l|l|l|}
\hline & $\begin{array}{l}\text { Strongly } \\
\text { agree }\end{array}$ & $\begin{array}{l}\text { Somewhat } \\
\text { agree }\end{array}$ & Indifferent & $\begin{array}{l}\text { Somewhat } \\
\text { disagree }\end{array}$ & $\begin{array}{l}\text { Strongly } \\
\text { disagree }\end{array}$ \\
\hline $\begin{array}{l}\text { All professional translators } \\
\text { should have a degree in trans- } \\
\text { lation. }\end{array}$ & $47.2 \%$ & $43.8 \%$ & $4.5 \%$ & $4.5 \%$ & $0.0 \%$ \\
\hline $\begin{array}{l}\text { Translation is best learned on } \\
\text { the job. }\end{array}$ & $49.4 \%$ & $43.8 \%$ & $3.4 \%$ & $3.4 \%$ & $0.0 \%$ \\
\hline
\end{tabular}

Table 6. On-the-job vs. formal training

About half the respondents (47.2\%) strongly agreed that all professional translators should have a degree in translation, and half of the respondents (49.4\%) strongly agreed that translation is best learned on the job. Further, $43.8 \%$ of the respondents somewhat agreed with both statements. It may be inferred that the majority of the respondents agree on the importance of both on-the-job training and formal training, some with a slightly stronger emphasis on either formal training or on-the-job training. They do not see the two activities as being mutually exclusive. While emphasizing that there is need for a degree in translation to be employed in the translation market, many translators - all holding a degree in translation - expressed in their comments in the survey and in interviews that they did not feel prepared to enter the market when they graduated, and learnt the profession on the job.

The respondents were also asked how well their academic training prepared them for their professional work as translators. Eighty-nine participants replied to this question.

\begin{tabular}{lll}
\hline $\begin{array}{l}\text { How well academic training prepared for } \\
\text { professional work }\end{array}$ & Response percent & Response count \\
\hline Extremely well & 12.4 & 11 \\
\hline Fairly well & 51.7 & 46 \\
\hline Only basic preparation & 34.8 & 31 \\
\hline Badly & 1.1 & 1 \\
\hline Very badly & 0.0 & 0 \\
\hline Total & 100.0 & 89 \\
\hline
\end{tabular}

Table 7. How well academic training prepared for professional work

Slightly over half of the respondents (51.7\%) agreed that the academic training had prepared them fairly well and $12.4 \%$ said that the training prepared them extremely well for professional work, whereas one third of the respondents $(34.8 \%)$ said that the academic training had provided only basic preparation. According to this result, the majority of the respondents $(64.1 \%)$ have a positive opinion of their training, apparently rejecting the assumption that training practices fail to correspond to market needs. The number of respondents that claimed to have had only basic preparation is nevertheless still high (34.8\%). This suggests that graduates believe academic trai- 
ning is required to be a translator, but they need to acquire more professional competence in training.

\section{Discussion}

This section presents a discussion of data and results obtained in the analysis of documents related to the translation profession, and the survey and interviews with graduates. The themes that are brought forward are education, legal instruments and professional associations illustrating the degree of professionalization in translation, and varied profiles of translation graduates on the market illustrating the (lack of) solidity.

\subsection{Steps taken on the way to professionalization}

As suggested in the theoretical section, education/training, legal instruments that regulate the market and professional associations are indicative of a high-status, solid or well-established profession. With regard to the aspect of education, translator-training programs in universities have been increasing in number and diversifying. However, no data are available about the proportion of translators holding a degree on the job market. University-based training programs produce graduates supposedly equipped with the advanced knowledge and specific skills required to translate. Holding a degree in translation is nevertheless not one of the requirements for entry to the market, although my impression is that the number of job advertisements seeking specifically a translator with a degree in translation has increased in recent years. This is in line with the results of Pym et al. (2012: 20), who also report that academic (or formal) qualification is not required to be employed as a translator in any of eight countries they surveyed.

This study shows that producing professionals for the market is not the only role of universitybased training programs. As pointed out in Section 4.2., academics in these programs act as a stakeholder in initiatives taken to improve the profession (e.g. adoption of national standards), take part in the establishment of national associations (e.g. Translation and Interpreting Association of Turkey), and produce knowledge (e.g. academic journals and conferences) to contribute to the cultivation of professionals and to ensure public recognition.

While well-established university-based training programs are an evident sign of enhanced professionalization, there has been a growing discussion on the increasing number of translator-training programs with reference to the relative needs on the job market and employment issues. A recent report by the Prime Ministry Directorate for Administration Development (2015: 50-51) estimates that the number of "qualified"17 translators in Turkey is 10,000 , and the number of translation companies is about 5,000. The number of translators employed in civil service is 2,500 . Undergraduate and associate degree programs are estimated to produce over 4,000 graduates per year. A detailed needs analysis is required to determine the rate of graduates employed on the translation market every year, however the figures cited suggest that the number of graduates may be greater than the number needed in the sector.

The adoption of the National Occupational Standards for translators and interpreters (2013) with common efforts of all stakeholders contributes to the visibility, acknowledgement and recognition of the profession, although it is not a legally binding instrument that could regulate entry to the profession. Furthermore, the adoption of TS EN ISO 17100 and the bill of law proposed to establish a union of translators' chambers are promising attempts that are likely to contribute to the development of translation from a semi-profession to a full-fledged profession.

Another major step toward professionalization is that translator associations have been established to improve the status of the profession and defend the rights of translators. However, in the Turkish context, the number of translators represented by these associations is low (Eruz 2012: 18). Pym et al. (2012: 135) report that the number of members is 281 in TÜÇED, 60 in Çe-

17 No definition of "qualified" is provided. 
viri Derneği, and 180 in ÇEVBİR. Considering that the total number of translators was above estimated as 10,000 , these are low numbers indeed. Further criticisms about associations were raised in the Translation Platform held by the Ministry of European Union, which suggested that the associations generally fail to collaborate with each other (Özaydın 2012: 64), and they would need to develop common strategies to enable global representation (Kartal 2012: 41), or even to be combined under a single a federation (Erbil 2012: 14). Furthermore, in Turkey, the associations do not provide nationwide acknowledged qualifications (examination or certification systems) such as the Chartered Institute of Linguists Diploma in Translation in the UK, the American Translators Association certification in the US, or the Canadian Translators, Terminologists and Interpreters Council certification that are based on a thorough examination and assessment process.

Professional associations and training programs are making efforts to enhance collaboration. There are meetings where all stakeholders of the market come together (e.g. Translation Platform held by the Ministry of European in 2012), training programs organized by associations, and an increasing number of activities to bring stakeholders (including employers) together with students in translator-training programs. All these activities indicate that there are now greater efforts to promote the functioning of associations, to coordinate individual efforts of stakeholders, and hence to foster the professionalization and solidity of the translation profession.

\subsection{Varied profile of translators - so what?}

The finding related to the profile of translators suggests that the number of women far outweighs the number of men on the market. As pointed out in Section 2.2., this is one of the factors that indicate a lack of solidity in the profession. The result is also comparable with other studies conducted across the world, as reported in Pym et al. (2012: 85). With regard to the professional profile of translation program graduates, 89 out of 125 university graduates reported to be working as a translator. However, not all the respondents had translation as their main role. The rate of the respondents whose first role was translation was $57 \%$, or only slightly over half. Most of these respondents were in-house translators.

A high proportion of freelancers may also suggest that a profession lacks solidity. In the present study, while about half of the respondents were freelancing, the majority of graduates adopted freelancing as a second role. This result does not seem to be consistent with previous surveys such as Olohan (2007), Byrne (2003) and Fraser/Gold (2005), which emphasized freelancing as a preferred choice rather than an obligation. It seems that in Turkey this is not the case, probably because of economic instability. This finding, together with the higher rate of freelancing among younger graduates, further suggests that freelancing is considered a temporary choice in the Turkish translation market, rather than a preferred mode of working.

As far as commitment to translation as a profession is concerned, the majority of the translation graduates surveyed had a positive perception of training programs. Some of them are nevertheless inclined to shift to other professions, mainly language teaching. They mentioned especially lack of standards, imbalance between effort and income, and the stress factor to explain why they did not prefer to exercise the translation profession. These complaints are mainly linked to lack of regulation on the market.

\section{Conclusion}

The present article has examined the solidity of the translation profession in Turkey both in terms of the degree of professionalization and the findings of a survey on the profile of translators. The results suggest that all traits of an established profession are still not present while definite steps have been taken on the way to professionalization.

The training programs, as workforce providers to the market, are well established. Translator training has been carried out in university-based Translation and Interpreting or Translation Studies programs since the first half of the 1980s. With an upsurge in the number of master's and doc- 
torate programs in Translation Studies, universities also train translator trainers. In recent years, instruments have been introduced to improve the current state of the profession, and associations have been established to promote translators' rights and to bring stakeholders together. However, the number of translators represented by associations is low. Moreover, the associations do not offer an examination and certification system that allows translators to provide evidence for credibility on the market. Lack of certification or any other tool for earning credibility is a factor that is likely to have negative effects for both translators and clients. Qualifications required to enter the profession are not specified. Anyone with bilingual competence can become a translator. This also applies to sworn translators authorized to translate official documents.

Translation program graduates generally have a positive perception of training programs and are willing to be employed as translators on the market. Over $70 \%$ of the respondents worked as translators, although not all of them were full-time translators. However, lack of regulation and insecurity make some of them seek other career opportunities especially in teaching. Freelancing is mostly a secondary role and a transitory option while they look for a 'better' job opportunity.

Considerable progress has been made in recent years to improve the translation profession. Yet, there is still a need for further steps particularly with regard to entry to the market. The findings in the Turkish context echo Pym et al.'s (2016: 50) conclusion that "[t]he kind of legally protected title that is based on an academic degree and membership of an association seems not likely to happen anytime soon in the case of translation".

The present study describes the degree of professionalization and solidity in translation drawing on the analyses of available documents and data on translators' profile. Further research may focus on collecting qualitative data to describe the translation profession based on 'actual' experience of various stakeholders. 


\section{References}

Abercrombie, Nicholas/Hill, Stephen/Turner, Bryan S. 2006: The Penguin Dictionary of Sociology. $5^{\text {th }}$ ed. London: Penguin Books.

Byrne, Jody 2003: Freelance Translation: Teaching Students to Create Their Own Jobs. In Gouadec, Daniel/Toudic, Daniel (eds.), Traduction, Terminologie, Rédaction. Paris: La Maison du Dictionnaire, 161-174.

Chan, Andy Lung Jan 2008: Information Economics, The Translation Profession and Translator Certification. Doctoral Thesis. Tarragona: Universitat Rovira i Virgili. [online] http://www.tdx.cat/handle/10803/8772 (accessed 15 November 2017).

Chan, Andy Lung Jan 2009: Effectiveness of Translator Certification as a Signaling Device: Views from the Translator Recruiters. In Translation and Interpreting Studies 4(2), 155-171.

Chan, Andy Lung Jan 2013: Signal Jamming in the Translation Market and the Complementary Roles of Certification and Diplomas in Developing Multilateral Signaling Mechanisms. In The International Journal for Translation and Interpreting Research 5(1), 211-221. [online] http://www.trans-int.org/index.php/transint/article/view/236/124 (accessed 15 November 2017).

Choi, Jungwha/Lim, Hyang-Ok 2002: The Status of Translators and Interpreters in Korea. In Meta, 47 (4), 627-635.

Dam, Helle V./Zethsen, Karen Korning 2008: Translator Status: A Study of Danish Company Translators. In The Translator 14, 71-96. [online] http://www.tandfonline.com/doi/pdf/10.1080/13556509.2008.10799250 (accessed 2 February 2017).

Dam, Helle V./Zethsen, Karen Korning 2009: Who Said Low Status? A Study on Factors Affecting the Perception of Translator Status. In The Journal of Specialised Translation 12, 2-36. [online] http://www.jostrans.org/issue12/ art_dam_zethsen.php (accessed 2 February 2017).

Dam, Helle V./Zethsen, Karen Korning 2010: Helpers and Opponents in the Ongoing Battle of an Emerging Profession. In Target 22(2), 194-211.

Dam, Helle V./Zethsen, Karen Korning 2011: The Status of Professional Business Translators on the Danish Market: A Comparative Study of Company, Agency and Freelance Translators. In Meta 56(4), 976-997.

Dam, Helle V./Koskinen, Kaisa 2016: The Translation Profession: Centres and Peripheries. In The Journal of Specialised Translation 25, 2-14. [online] http://www.jostrans.org/issue25/art_intro.pdf (accessed 15 April 2017).

Dam, Helle V./Zethsen, Karen Korning 2016: I Think It Is a Wonderful Job. On the Solidity of the Translation Profession. In The Journal of Specialised Translation 25, 174-187. [online] http://www.jostrans.org/issue25/art_dam.pdf (accessed 15 April 2017).

Drechsel, Robert E. 2000: The Paradox of Professionalism: Journalism and Malpractice. In University of Arkansas Little Rock Law Review 23(1), 181-196. [online] http://lawrepository.ualr.edu/lawreview/vol23/iss1/11 (accessed 29 December 2017).

Erbil, Seher. 2012. Uygulamalı Çevirmenlik Eğitim Formasyon Projesi Önerisi [A Project Proposal for Vocational Translator Training]. In Proceedings of the Ministry for EU Affairs Translation Platform, 13-16. [online] http:// www.ab.gov.tr/files/ceb/Ceviri_Platformu_Resimleri/platform_bildirileri.pdf (accessed 15 April 2017).

Ersoy, Hüseyin/Odacioğlu, Mehmet Cem 2014: Problems Faced by Freelance Translators in Turkey, Effects of These Problems and Suggestions. In Turkish Studies 9(6), 367-378. [online] http://www.turkishstudies.net/Makaleler/116 3575427_25ErsoyHüseyin-vd-edb-367-378.pdf (accessed 15 November 2017).

Eruz, Sakine 2012: Çeviri Derneği Ve Türkiye'de Çevirmenlik Mesleğinin Statüye Kavuş(a)ma(ma)sı Üzerine On Üç Y1llık Gel Gitli Bir Öykü [The Translation and Interpreting Association of Turkey and the 13-Year Story of the Status of the Translation Profession in Turkey]. In Proceedings of the Ministry for EU Affairs Translation Platform, 17-23. [online] http://www.ab.gov.tr/files/ceb/Ceviri_Platformu_Resimleri/platform_bildirileri.pdf (accessed 15 April 2017).

Fitch, Kate 2016: Professionalizing Public Relations. History, Gender and Education. London: Palgrave Macmillan.

Fraser, Janet/Gold, Michael 2001: 'Portfolio Workers': Autonomy and Control amongst Freelance Translators. In Work, Employment and Society 15(4), 679-697.

Higher Education Council of Turkey = T. C. Yükseköğretim Kurulu 2007: Türkiye'nin Yükseköğretim Stratejisi [The Higher Education Strategy of Turkey]. [online] http://www.yok.gov.tr/documents/10279/30217/yok_strateji_ kitabi/27077070-cb13-4870-aba1-6742db37696b (accessed 15 April 2017).

Kafi, Mohsen/Khoshsaligheh, Masood/Hashemi, Mohammad Reza 2017: Translation Profession in Iran. Current Challenges and Future Prospects. In The Translator, 1-15. [online] http://www.tandfonline.com/doi/full/10.1080/13556 509.2017.1297693 (accessed 30 December 2017). 
Kartal, Kamil 2012: Çeviri Sektörü: Sorunlar ve Çözüm Önerileri [The Translation Sector: Problems and Proposals for Solution]. In Proceedings of the Ministry for EU Affairs Translation Platform, 40-42. [online] http://www.ab.gov.tr/ files/ceb/Ceviri_Platformu_Resimleri/platform_bildirileri.pdf (accessed 15 April 2017).

Katan, David 2009a: Translation Theory and Professional Practice: A Global Survey of the Great Divide. In Hermes 42, 111-154. [online] https://tidsskrift.dk/her/article/view/96849 (accessed 15 April 2017).

Katan, David 2009b: Occupation or Profession: A Survey of the Translators' World, Translation and Interpreting Studies 4(2), 187-209.

Katan, David 2010: Status of Translators. In Gambier, Yves/van Doorslaer, Luc (eds.), Handbook of Translation Studies, Vol. 2. Amsterdam/Philadelphia: John Benjamins, 146-152.

Keogh, Johann 1997: Professionalization of Nursing. Development, Difficulties and Solutions. In Journal of Advanced Nursing 25, 302-308. [online] http://onlinelibrary.wiley.com/doi/10.1046/j.1365-2648.1997.1997025302.x/epdf (accessed 29 December 2017).

Kobya, Senem/Karabacak, Funda (eds.) 2015: Çeviri Kitabı [The Translation Book]. Istanbul: Universal.

Lagoudaki, Elina 2006: Translation Memories Survey 2006: Users' Perceptions around TM Use. In Translating and the Computer 28. [online] http://mt-archive.info/Aslib-2006-Lagoudaki.pdf (accessed 15 April 2017).

McDonough, Dolmaya 2011: Moral Ambiguity: Some Shortcomings of Professional Codes of Ethics for Translators. In The Journal of Specialised Translation 15, 28-49. [online] http://www.jostrans.org/issue15/art_mcdonough.pdf (accessed 30 November 2017).

Millerson, Geoffrey 1964: The Qualifying Associations: A Study in Professionalization. London: Routledge and Kegan Paul.

Olohan, Maeve 2007: Economic Trends and Developments in the Translation Industry. What Relevance for Translator Training? In The Interpreter and Translator Trainer 1(1), 37-63.

Olohan, Maeve 2012: Volunteer Translation and Altruism in the Context of a Nineteenth-Century Scientific Journal. In The Translator, 18(2), 193-215. [online] http://www.tandfonline.com/doi/pdf/10.1080/13556509.2012.10799508?n eedAccess=true, $($ accessed 15 November 2017).

Olohan, Maeve 2014: Why Do You Translate? Motivation to Volunteer and TED Translation. In Translation Studies 7(1), 17-33.

Özaydın, Ümit 2012: AB Sürecinde Sözlü ve Yazılı Çeviri Standartları [Translation and Interpreting Standards in the EU Process]. In Proceedings of the Ministry for EU Affairs Translation Platform. 64. [online] http://www.ab.gov.tr/ files/ceb/Ceviri_Platformu_Resimleri/platform_bildirileri.pdf (accessed 15 April 2017).

Özkaya, Esra 2015: Interpreting within the European Qualifications Framework: Turkish Experience with the New National Standards. In I. U. Journal of Translation Studies 9(1), 55-68. [online] http://dergipark.gov.tr/uploads/ issuefiles/010f/5eae/f1f5/589d6f3c8c67a.pdf (accessed 15 November 2017).

Pérez-González, Luis/Susam-Saraeva, Şebnem 2012: Non-professionals Translating and Interpreting. Participatory and Engaged Perspectives. In The Translator 18(2), 149-165. [online] http://www.tandfonline.com/doi/pdf/10.1080/13 556509.2012.10799508?needAccess=true (accessed 15 November 2017).

Prime Ministry Directorate for Administration Development 2011 = Başbakanlık İdareyi Geliştirme Başkanlığ 2011: Türkiye'de Çevirmenlik Mesleği [The Translation Profession in Turkey] [online] http://www.igb.gov.tr/Kutuphane/ Araştırma\%20Raporu\%20-\%20Türkiyede\%20Çevirmenlik\%20Mesleği.pdf (accessed 1 April 2017).

Prime Ministry Directorate for Administration Development 2015 = Başbakanlık İdareyi Geliştirme Başkanlığı 2015 : Türkiye'de Çevirmenlik Mesleği [The Translation Profession in Turkey] [online] http://buder.org.tr/Kutuphane/ ÇEVİRMENLIK\%20RAPORU10.08.2015.pdf (accessed 1 April 2017).

Pym, Anthony/Grin, François/Sfreddo, Claudio/Chan, Andy L. J. 2012: The Status of the Translation Profession in the European Union. Studies on Translation and Multilingualism 7. Luxembourg: Publication Offices of the European Union [online] http://ec.europa.eu/dgs/translation/publications/studies/translation_profession_en.pdf (accessed 20 February 2017).

Pym, Anthony/Orrego-Carmona, David/Torres-Simón, Esther 2016: Status and Technology in the Professionalisation of Translators. Market Disorder and the Return of Hierarchy. In Journal of Specialised Translation 25, 33-53. [online] http://www.jostrans.org/issue25/art_pym.php (accessed 20 February 2017).

Ruokonen, Minna 2013: Studying Translator Status: Three Points of View. In Eronen, Maria/Rodi-Risberg, Marinella (eds.), Haasteena Näkökulma, Perspektivet som Utmaning, Point of View as Challenge, Perspektivität als Herausforderung. VAKKI-Symposiumi XXXIII. Vaasa: VAKKI, 327-338.

Ruokonen, Minna 2016: Realistic but Not Pessimistic: Finnish Translation Students' Perceptions of Translator Status. In The Journal of Specialised Translation 25, 188-212. [online] http://www.jostrans.org/issue25/art_ruokonen.pdf (accessed 15 November 2017). 
Séguinot, Candace 2007: Translation and the Changing Profession: A Cross-disciplinary Perspective. In TTR: Traduction, Terminologie, Rédaction 20(1), 171-191. [online] http://www.erudit.org/fr/revues/ttr/2007-v20-n1ttr2280/018502ar/ (accessed 15 November 2017).

Sela-Sheffy, Rafeket 2006: The Pursuit of Symbolic Capital by a Semi-Professional Group: The Case of Literary Translators in Israel. In Wolf, Michaela (ed.), Übersetzen - Translating - Traduire. Towards a "Social Turn"? Vienna/ Munich: LIT, 243-252.

Sela-Sheffy, Rafeket 2016: Elite and Non-elite Translator Manpower. The Non-professionalized Culture in the Translation Field in Israel. In The Journal of Specialised Translation 25, 54-73. [online] http://www.jostrans.org/issue25/ art_sela.pdf (accessed 15 November 2017).

Setton, Robin/Guo Liangliang, Alice 2009: Attitudes to Role, Status and Professional Identity in Interpreters and Translators with Chinese in Shanghai and Taipei. In Translation and Interpreting Studies 4(2), 210-238.

Stejskal, Jiri 2004: Certification of Translators and Interpreters: Seminar on Standards and Certifications in the T\&I Industry [online] http://www.jtpunion.org/getattachment/O-profesi-Akce/Odborne/Neco-ke-cteni/Credentialingof-Translators-and-Interpreters-An-I/IMG-ppt-certif.ppt.aspx (accessed 15 April 2017).

The Proceedings of the Ministry for EU Affairs Translation Platform 2012: [online] http://www.ab.gov.tr/files/ceb/ Ceviri_Platformu_Resimleri/platform_bildirileri.pdf (accessed 15 April 2017).

Toudic, Daniel 2012: The OPTIMALE Employer Survey and Consultation [online] https://www.euatc.org/images/Optimale_WP4_Synthesis_report.pdf(accessed 15 November 2017).

Turkish Standards Institution = Türk Standardları Enstitüsü 2015: TS EN ISO 17100 Çeviri Hizmetleri - Çeviri Hizmetleri İçin Gereklilikler [Translation Services - Requirements for Translation Services]. ${ }^{\text {st }}$ ed. Ankara: Türk Standardları Enstitüsü.

Uysal, Nazan Müge/ Odacıoğlu, Mehmet Cem/Köktürk, Şaban 2015: Current Position of Translatorship in Turkey in Terms of Professionalization, Problems and Suggestions. In The Journal of International Social Research 8(36), 257-266. [online] http://www.sosyalarastirmalar.com/cilt8/sayi36_pdf/1dil_edebiyat/uysal_muge_cemodacioglu. pdf (accessed 15 November 2017).

Vocational Qualifications Authority = T. C. Mesleki Yeterlilik Kurumu 2013: Ulusal Meslek Standard 1 Çevirmen [National Occupation Standard for Translators] [online] https://portal.myk.gov.tr/index.php? dl=2016/1/13/0.290311001452678984_cevirmen_seviye_6_ums.pdf (accessed 15 November 2017).

Weiss-Gal, Idit/Penelope Welbourne 2008: The Professionalisation of Social Work: A Cross-National Exploration. In International Journal of Social Welfare 17, 281-290.

Yilmaz Gümüş, Volga 2014: Teaching Technology in Translator-Training Programs in Turkey. In Torres-Simón, Esther/ Orrego-Carmona, David (eds.), Translation Research Projects. Tarragona: Intercultural Studies Group, 25-35.

Y1lmaz-Gümüş, Volga 2017: Training Translators for the Market in Turkey: What Should We Teach to Future Translators? In Journal of Comparative Literature and Translation Studies 5(1), 1-10. [online] http://www.journals.aiac. org.au/index.php/IJCLTS/article/view/3073 (accessed 15 November 2017). 